\title{
Immunotherapy for B-acute Lymphoblastic Leukemia by Focusing on Monoclonal Antibody and CAR- T-cell Application
}

\author{
Seyedeh M. MOHAMMADI ${ }^{1}$, Daryosh M. NEJAD ${ }^{2}$, Hojjatollah N. CHAROUDEH ${ }^{1}$ \\ ${ }^{1}$ Tabriz University of Medical Sciences, Stem Cell Research Center, Tabriz \\ ${ }^{2}$ Tabriz University of Medical Sciences, Department of Anatomical Sciences, Tabriz, IRAN
}

\begin{abstract}
Considerable advances have been made in treatment of acute lymphoblastic leukemia (ALL) with an overall survival rate of $85 \%$ in children, and in great improvement in adults. Despite this improvement and the accessibility of hematopoietic stem cell transplantation, relapsed ALL remains a leading cause of childhood mortality emphasizing the need of new approaches on therapy. Leukemia cells express numerous surface antigens amenable to target therapies, consist of CD20, CD22, and CD19. Monoclonal antibodies which target these antigens have improved the outcomes in B-cell ALL. Rituximab is the best known monoclonal antibody which is routinely used in combination with chemotherapy for treatment of adult B-cell ALL. Monoclonal antibodies including unconjugated and conjugated antibodies to cytotoxic agents for treatment of B-cell ALL are now under investigation. In this article we update the results and current status of investigational monoclonal antibody-based therapies in ALL.
\end{abstract}

Keywords: Immunotherapy, Lymphoblastic leukemia, Monoclonal antibody

ÖZET

\section{Monoklonal Antikor ve CAR-T-Cell Uygulamasına Odaklı B-akut Lenfoblastik Lösemi İmmünoterapisi}

Akut lenfoblastik lösemi (ALL) tedavisinde, genel sağkalım oranı çocuklarda \% 85 ve yetişkinlerde büyük düzelme olmak üzere önemli ilerlemeler kaydedilmiştir. Bu gelişmeye ve hematopoietik kök hücre naklinin erişilebilirliğine rağmen, nükseden ALL, çocuklukta mortalitenin önde gelen bir nedenidir ve bu durum tedavide yeni yaklaşımların gerekliliğini vurgulamaktadır. Lösemi hücreleri hedef terapilere uygun, CD20, CD22 ve CD19'dan oluşan sayısız yüzey antijeni eksprese eder. Bu antijenleri hedefleyen monoklonal antikorlar, B-hücreli ALL sonuçlarını iyileștirmiştir. Rituximab, erişkin B hücreli ALL tedavisinde kemoterapi ile birlikte rutin olarak kullanılan en iyi bilinen monoklonal antikordur. B hücreli ALL tedavisinde, sitotoksik ajanlara konjuge olmayan ve konjuge antikorları içeren monoklonal antikorlar günümüzde araştııımaktadır. Bu makalede, ALL'nin araştııımakta olan monoklonal antikor-tabanlı tedavilerinin sonuçlarını ve mevcut durumu güncelliyoruz.

Anahtar Kelimeler: İmmünoterapi, Lenfoblastik lösemi, Monoklonal antikor 


\section{INTRODUCTION}

Acute lymphoblastic leukemia (ALL) is the most common cancer in children, with top prevalence in the ages of 2 and 5 years and the important cause of mortality from hematological cancers in adults with second peak after the age of 50 years. ${ }^{1-2}$ This cancer originates in a single $\mathrm{B}$ and $\mathrm{T}$ lymphocyte progenitor then, as a result of proliferation and accumulation of leukemia cells normal hematopoiesis is suppressed in patients. Considerable advances have been made in treatment of ALL especially in children, with an overall survival from $10 \%$ in 1960 to $85 \%$ in $2000^{3}$ which is one of the most success stories in the history of modern medicine. About adults the outcome is being improved but it remains poor compared to children with a longterm survival of only $45 \%{ }^{1}$ So the prognosis remains poor for some patients with ALL and definitely, further approaches are needed in treatment.

Recently, significant improvement has been achieved by targeted therapy, mainly treatment with $m A b s$ which are designed to bind to a specific surface marker expressed on leukemic cells. Monoclonal antibodies have various mechanisms of action, including antibody-dependent cellular cytotoxicity, complement dependent cytotoxicity, and induction of apoptosis. They include unconjugated form (e.g., rituximab), conjugated to cytotoxic agents (e.g., inotuzumab), conjugated to toxins such as Diptheria toxins (e.g., moxetumomab pasudotox) (Figure 1) and the recently established class of Bi-specific T-cell Engaging Monoclonal Antibody that occupy CD3 on the surface of cytotoxic T-cells and readdress cytotoxic $\mathrm{T}$ lymphocytes to lyse CD19+ target ALL cells (e.g., blinatumomab) (Figure 2) ${ }^{4-5}$ Variety of specific antigens such as CD19, CD20, CD22, and CD52 studied to date and the most experience is available for antiCD20 antibody rituximab which has been combined with chemotherapy and has made promising results in treatment of Burkitt ALL and CD20positivepre-B ALL. ${ }^{6-7}$ In this article we review the results and current status of investigational monoclonal antibody-based therapies in ALL.

\section{UNCONJUGATED MONOCLONAL ANTI- BODIES}

\subsection{Rituximab}

Rituximab is a chimeric monoclonal antibody, approved in 1997 by the FDA as the first anticancer monoclonal antibody, that targets CD20. ${ }^{8} \mathrm{CD} 20$ is a transmembrane phosphoprotein that is expressed on the surface of normal B-cells during all stages of differentiation ${ }^{9}$, as well as on $40 \%$ to $50 \%$ of the precursor B-cell ALL and nearly on 80-100\% of the Mature B-ALL and Burkitt leukemia. ${ }^{10-11}$ In adult patients with ALL CD20 positivity was associated with a higher rate of relapse $(65 \%$ vs $42 \%$ ), and lower 3-year overal survival (27\% vs $40 \%$ ). Thomas et al have shown that the addition of rituximab to hyper-CVAD [fractionated cyclophosphamide, vincristine, doxorubicin, and dexamethasone] chemotherapy has significantly improved cure rate in Burkitt ALL. ${ }^{12}$ Rituximab targets CD20 and kills cells, by antibody-dependent cellular and complement-mediated cytotoxicity as well as by inducing apoptosis directly. ${ }^{13-14}$ The addition of rituximab in Younger patients(age $<60$ years) with CD20 positive ALL improved complete remission (CR) duration ( $70 \%$ vs $38 \%$ ). ${ }^{15}$ The similar findings have been reported by GMALL Group for treatment of ALL in Adults and the addition of rituximab was associated with improved 5-year survival. ${ }^{16}$ These studies recommend that the administration of rituximab to chemotherapy has improved outcome in CD20 positive pre-B ALL, mainly among younger adults. Further studies are recommended to address the role of prolonged rituximab therapy (beyond initial eight doses) and rituximab with reduced chemotherapy (to decrease risk of infection) in older patients. The utility of rituximab in most protocols have been limited to patients with CD20 expression of $20 \%$ or higher in the surface of leukemia cells, so among patients with low expression of CD20 (lower than 20\%) the addition of rituximab needs to be more explored.

\subsection{Ofatumumab}

Ofatumumab is a second-generation humanized anti-CD20 monoclonal antibody that binds an epitope different than rituximab. ${ }^{17}$ Ofatumumab 


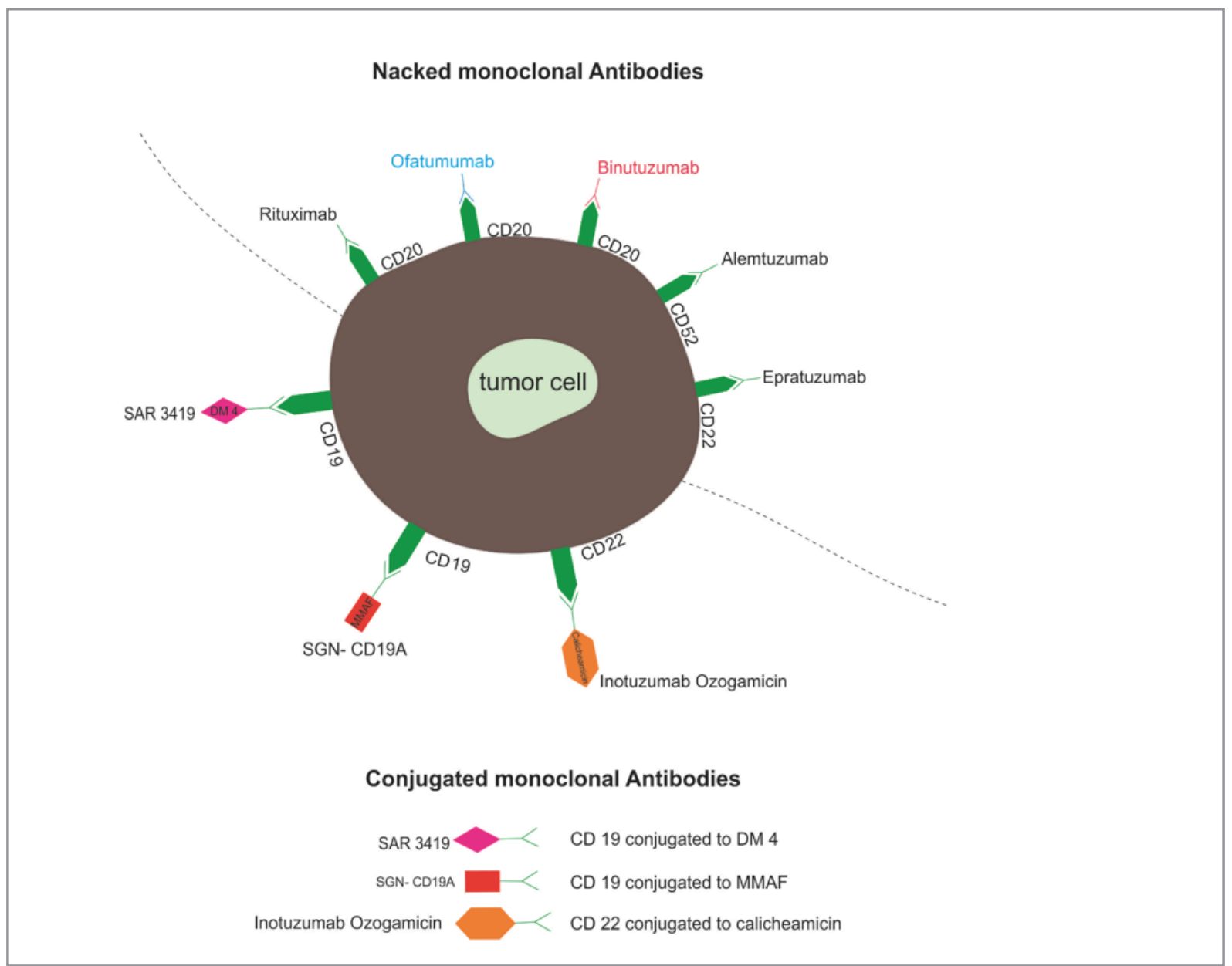

Figure 1. Varies monoclonal antibodies

exhibits increased binding to cell membrane and superior complement-dependent cytotoxicity than rituximab. It binds nearer to the cell membrane than rituximab that may be responsible for superior complement-dependent cytotoxicity. ${ }^{18-19}$ In chronic lymphocytic leukemia (CLL), ofatumumab has revealed noteworthy activity in patients with fludarabine-refractory as well as rituximab refractory. ${ }^{17}$ The administration of ofatumumab to the hyperCVAD regimen in patients with pre-B CD20 positive ALL, was found to be very effective. ${ }^{20}$

\subsection{Obinutuzumab}

Obinutuzumab (GA101) is a glyco-engineered type II humanized monoclonal antibody against CD20 which effectively induce direct cell death compared to rituximab and Ofatumumab. ${ }^{21-22}$ In untreated CLL patients, combination of Obinutuzumab with chlorambucil prolonged survival compared to chlorambucil alone. ${ }^{23}$ Gode et al in clinical trial study of CLL patients have compared treatment between Obinutuzumab plus chlorambucil (GClb) with rituximab plus chlorambucil ( $\mathrm{RClb})$ and have shown that $\mathrm{GClb}$ versus $\mathrm{RClb}$ improved the progression-free survival (PFS). However more research on Obinutuzumab in CD20-positive ALL patients is warranted. ${ }^{24}$

\subsection{Epratuzumab}

The high expression of $\operatorname{cd} 22$ on leukemic blasts (more than $90 \%$ of patients with ALL) and rapidly post internalization after antibody binding makes it an attractive target for monoclonal antibodies. ${ }^{25}$ Epratuzumab is a humanized CD22 IgG1 mono- 
clonal antibody which binds to the CD22 with following internalization of the receptor/antigen complex. ${ }^{26-27}$ Favorable overall response rate of $43 \%$, with single-agent epratuzumab therapy (360 $\mathrm{mg} / \mathrm{m}^{2} /$ dose) in patients with recurrent follicular lymphoma has increased the interest in this drug. ${ }^{27}$ Raetz et al studied epratuzumab in pediatric relapsed ALL. ${ }^{28}$ Therapy comprised of a single-agent epratuzumab which was administered twice weekly for two weeks at a dose of $360 \mathrm{mg} / \mathrm{m}^{2}$, followed by four weekly doses of epratuzumab in combination with standard four-drug re-induction therapy. Most patients had stable disease with single-agent epratuzumab, and one patient attained a partial response. Shah et al have reported that CD22 is expressed in $90 \%$ of leukemia blast of patients with relapsed and chemotherapy refractory B-precursor (pre-B) ALL suggesting the CD22 marker as an excellent potential therapeutic target in that patients. ${ }^{25}$ Of note administration of epratuzumab and its combination with other active agents require further investigation.

\subsection{Alemtuzumab}

CD52 is a surface antigen expressed in $36 \%$ to $66 \%$ of leukemia blasts, including B- and T-ALL and also acute myeloid leukemia but not on CD34 hematopoietic stem cells. ${ }^{29-30}$ Alemtuzumab is a humanized monoclonal antibody targets CD52 and have been first employed for ex vivo T-cell depletion of allogeneic bone marrow grafts to prevent GVHD cells. ${ }^{31}$ Clinical benefit and significant responses with acceptable toxicity occurred in treatment of the high-risk relapsed B-cell CLL patients with alemtuzumab resulted in its approval by the FDA for treatment of refractory CLL. ${ }^{32-33}$ Initial experiences using alemtuzumab proposed that alemtuzumab had limited activity in relapsed or refractory acute leukemia. Single-agent alemtuzumab was found to have poor results and no one of 6 adult patients with acute leukemia treated with alemtuzumab revealed any response. ${ }^{34}$ Similar results was achieved in a children with relapsed ALL treated with single agent alemtuzumab. Only one of 13 registered patients in that study attained a complete response with alemtuzumab and 4 had stable disease. ${ }^{35}$ Of note, alemtuzumab may have improved potency in patients that are resistant to rituximab following the down-regulation of CD20 and up-regulation of CD52. ${ }^{36}$ Thus studies of chemotherapy regimens combining alemtuzumab with or without rituximab will elucidate the potential benefit and toxicity profiles of this chemo immunotherapy approach.

\section{CONJUGATED MONOCLONAL ANTI- BODIES}

\subsection{Inotuzumab Ozogamicin}

Inotuzumab ozogamicin is a CD22 monoclonal antibody linked to a derivative of calicheamicin. ${ }^{37}$ Calicheamicin, a potent cytotoxic compound isolated from the actinomycete Micromonospora echinospora, induces double-strand DNA breaks resulting in cell apoptosis..$^{38,39}$

CD22 is being expressed in 60-90\% of B-lymphocyte malignancies but not on hematopoietic stem cells which make it a perfect target for antibody based therapy. ${ }^{40-41}$ In phase I study of Inotuzumab, as a single agent, Advani et al showed encouraging results with response rate of $39 \%$ in 79 patients with relapsed/refractory CD22+ NHL. ${ }^{42}$ A phase II study of inotuzumab monotherapy were performed by Kantarjian et al in treatment of patients with relapsed/refractory B-cell ALL. Overall, forty-nine patients were treated while CD22 expression was observed in B-lymphoblasts of all patients (more than 50\%). Nine (18\%) patients achieved complete response and 19 (39\%) achieved bone marrow complete response. The overall response rate (ORR) was $57 \%$, and the median survival was 5.1 months for all patients. The most common adverse events were transient fever and hypotension which usually occurred soon after the inotuzumab infusion and also reversible liver function abnormalities. ${ }^{43}$ Additionally Inotuzumab was administrated in combination with rituximab (R-INO) for treatment of patients with relapsed/ refractory CD20 positive /CD22 positive follicular lymphoma or DLBCL. ${ }^{44}$ The R-INO was well tolerated and results demonstrated high response rates and long PFS in Patients with relapsed follicular lymphoma or DLBCL with $\mathrm{R}$-INO treatment. Reversible thrombocytopenia was the most frequent adverse event. ${ }^{44}$ 
Inotuzumab in combination with low-intensity chemotherapy has also been tested in older patients with newly diagnosed B-ALL.A total of twenty-six patients with a median age of 67 years old (range 60-79) were treated with inotuzumab in combination with chemotherapy. The results was encouraging and ORR was 96\%; twenty one patients achieved CR (79\%) and 4 patients achieved CRp (CR with incomplete platelet recovery, $17 \%$ ). All patients achieving CR also had a negative MRD status. Most common grade 3-4 toxicities included infections (85\%), thrombocytopenia (65\%), hyperglycemia (44\%), increased bilirubin $(22 \%)$, intracranial hemorrhage $(15 \%)$ and elevated transaminases $(11 \%)$. The 1 -year progressionfree and overall survival rates were $86 \%$ and $81 \%$, respectively which was superior to the historical HCVAD +/- rituximab in similar patients' population (1-year survival rates of $78 \%$ and $60 \%$, respectively).$^{45}$ More studies is ongoing to evaluate the efficacy and influence of inotuzumab combined with chemotherapy in patients with B-cell ALL in earlier salvage therapy.

\subsection{SAR3419}

CD19, a transmembrane glycoprotein, is expressed by all types of $\mathrm{B}$ lymphocytes except mature plasma cells and also by the majority of B-cell precursor (BCP)-ALLs and B-cell non-Hodgkin lymphomas representing an attractive target for monoclonal antibody therapy. ${ }^{46-47}$

SAR3419 is a humanized IgG1 CD19 monoclonal antibody conjugated to the potent cytotoxic maytansinoid derivative drug DM4 48. Maytansine is a potent antimitotic agent, which binds to tubulin and inhibits tubulin polymerization and microtubule assembly similar to Vinca alkaloids resulting in cell cycle arrest in the $\mathrm{G} 2 / \mathrm{M}$ phase but with higher potency. ${ }^{49-50}$ Because of high systemic toxicity development of maytansinoids compounds as anticancer therapies was halted. Interest in maytansine as a therapeutic agent has recently been revived Following targeted delivery of drugs (e.g., binding to an antibody). In Mouse xenografts models of NHL, SAR3419 was more effective than CHOP (cyclophosphamide-Adriamycin-vincristine-prednisone) or rituximab at doses of $15 \mathrm{mg} / \mathrm{kg}$ or 30 $\mathrm{mg} / \mathrm{kg}$ with significant higher survival. ${ }^{51}$ In preclinical models SAR3419 significantly delayed the progression of four out of four CD19 positive Bcell precursor ALL and three out of three 3 mixed lineage leukemia xenografts and induced objective responses in all but one xenograft, but was ineffective against T-lineage ALL xenografts. ${ }^{52}$ To determine the maximum-tolerated dose (MTD) in patients with relapsed/refractory B-cell lymphoma, the phase 1 study of SAR3419 was conducted. ${ }^{53}$ The MTD was $160 \mathrm{mg} / \mathrm{m} 2$ intravenously once every 21 days. Thirty-nine patients were treated, twenty-six patients $(74 \%)$ had reduction in their tumor size; six of those patients achieved partial or complete remissions. The dose-limiting toxicity was reversible severe blurred vision associated with epithelial corneal changes. ${ }^{53}$ A Dose-Escalation study of SAR3419 in Patients with relapsed/refractory Bcell Non-Hodgkin lymphoma were also carried out by Ribrag et al. ${ }^{54} \mathrm{~A}$ total of 69 patients with R/R B-cell NHL were treated with SAR3419. Fortyfour patients were exposed weekly to SAR3419 on seven dose levels ranging from 5 to $70 \mathrm{mg} / \mathrm{m}^{2}$. Results showed that the dose of $55 \mathrm{mg} / \mathrm{m}^{2}$ is associated with efficacy when infused every week for 8 weeks, but also associated with late toxicities. To test an "optimized" administration schedule, twenty-five patients received the qw/q2w schedule at 55 $\mathrm{mg} / \mathrm{m}^{2}$ (four weekly (qw) doses followed by four biweekly (q2w) doses (qw/q2w)). The qw/q2w schedule showed the same activity without late toxicity 54. Recently phase 2 Study of SAR3419 as Monotherapy agent in patients with relapsed/ refractory ALL have been conducted in by Kantarjian et al. A total of 36 patients were treated including 19 patients during dose escalation phase and 17 patients during dose expansion phase. Three dose levels of SAR3419 were examined in escalation phase comprising 55, 70, and $90 \mathrm{mg} / \mathrm{m}^{2}$. Because of peripheral motor neuropathy which was observed at $90 \mathrm{mg} / \mathrm{m}^{2}$ dose thus $70 \mathrm{mg} / \mathrm{m}^{2}$ was selected for the dose-expansion phase. Among 17 patients treated at the $70 \mathrm{mg} / \mathrm{m}^{2}, 4$ have responded (objective response rate: $25.47 \%$ ) and duration of response (DOR) was 1.94 (range: 1-5.6) months concluding a low clinical response rate in patients with relapsed/refractory ALL 55. 


\subsection{SGN-CD19A}

SGN-CD19A is a novel antibody-drug conjugate composed of a humanized anti-CD19 conjugated to the microtubule-disrupting agent monomethyl auristatin $\mathrm{F}$ (MMAF). Upon binding to CD19, SGNCD19A internalizes and releases cys-mcMMAF, which binds to tubulin and induces $\mathrm{G} 2 / \mathrm{M}$ arrest and apoptosis in the targeted cells ${ }^{56}$ Two first-inhuman, phase 1 , dose-escalation studies has been initiated to investigate the safety, tolerability, pharmacokinetics (PK), and antitumor activity of SGN CD19A. One trial in adult and pediatric patients with relapsed or refractory B-cell acute lymphoblastic leukemia (B-ALL), Burkitt lymphoma or leukemia, or B-cell lymphoblastic lymphoma (B-LBL) in which the modified continual reassessment method (CRM) is being used for dose allocation and maximum tolerated dos. ${ }^{56}$ Thirteen patients (11 adults, 2 pediatric) with relapsed or refractory B-cell ALL $(n=9)$ and highly aggressive lymphoma (3 B-LBL, 1 Burkitt lymphoma) have been treated in this ongoing study. SGN-CD19A is administered IV on days 1 and 8 of every 21-day cycles at up to 7 cohort-specific doses ranges 0.3 $2.3 \mathrm{mg} / \mathrm{kg}$. No MTDs have been reported so far in both populations. Antitumor activity has been observed and one of the eight evaluable patients with ALL achieved complete remission (1 adult at $1.3 \mathrm{mg} / \mathrm{kg}$ ). Adverse events were nausea (64\%), fever $(55 \%)$, chills $(36 \%)$, and headache $(27 \%)$. The study now is ongoing. ${ }^{57} \mathrm{~A}$ second trial is evaluating the safety and tolerability of SGN-CD19A every 3 weeks in adult patients with relapsed or refractory B-lineage non-Hodgkin lymphoma (B-NHL). ${ }^{58} \mathrm{~A}$ phase 2 clinical trial is evaluating 19A in combination with chemotherapy for relapsed diffuse large B-cell lymphoma (DLBCL). A phase 2 trial in frontline DLBCL is planned for $2016 . .^{59}$

\subsection{Blinatumomab (CD3+CD19+ Bi-specific T- cell Engaging Monoclonal Antibody)}

Blinatumomab is the first member of the novel class of bispecific single-chain antibodies that engages surface $\mathrm{CD} 3$ on cytotoxic $\mathrm{T}$ cells and redirects them to lyse CD19 expressing B lymphoblasts. So, it contains 2 antigen-binding sites, one specific to T cells and the other one to the CD19 positive leukemia cells, on binding to CD19, the cytotoxic $\mathrm{T}$ cells become activated and induce perforin-mediated death on the target cells Figure 2. ${ }^{60}$ Blinatumomab was first explored in patients with relapsed B-cell NHL. The clinical activity and safety of blinatumomab were examined in 38 patients, who received blinatumomab at doses from $0.0005-0.06 \mathrm{mg} / \mathrm{m}^{2} / \mathrm{d}$. Dose-response relationship was observed and patients, who received blinatumomab at doses of $0.015 \mathrm{mg} / \mathrm{m}^{2} /$ day and higher achieved partial and complete tumor regressions. All seven patients received blinatumomab at a dose level of 0.06 milligrams showed tumor regression and clearance of tumor cells from bone marrow and liver. ${ }^{61}$ MRD positivity in adult ALL is an adverse prognostic factor and is associated with a high risk of relapse. The first pilot trial was conducted in twenty-one adult patients with persistent MRD. ${ }^{60}$, ${ }^{62}$ Patients received blinatumomab at a dose of 15 $\mu \mathrm{g} / \mathrm{m}^{2}$ by continuous infusion over 24 -hours daily for four-week. Sixteen of 21 patients became MRD negative, including 12 patients who had been molecularly refractory to prior chemotherapy. Overall Probability of relapse-free survival was $78 \%$ at a median follow-up of 15 month and in patients who did not undergo allogeneic stem-cell transplantation was $60 \%$. The most frequent grade 3 and 4 adverse event was lymphopenia, which was completely reversible like most other adverse events. ${ }^{60}$ The Final findings of this patient population has been published recently. With a median follow-up of 33 months, the hematologic relapse-free survival for the entire 20 patients was $61 \%$, and it was $65 \%$ for 9 patients who underwent allogeneic hematopoietic stem cell transplantation after blinatumomab treatment. Based on results blinatumomab can induce long-lasting complete remission in B-cell ALL patients with persistent or recurrent MRD and may lead in approval of blinatumomab for MRD-positive B-cell AL treatment. ${ }^{62}$ Additionally blinatumomab was also evaluated in 3 children with relapsed ALL post allogeneic stem cell transplant. All children achieved complete remission after blinatumomab with tolerable toxicity. ${ }^{63}$ Blinatumomab was also investigated in adults with relapsed/ refractory pre-B ALL patients. Interim analysis reported CRs in 12 of 18 treated patients, 


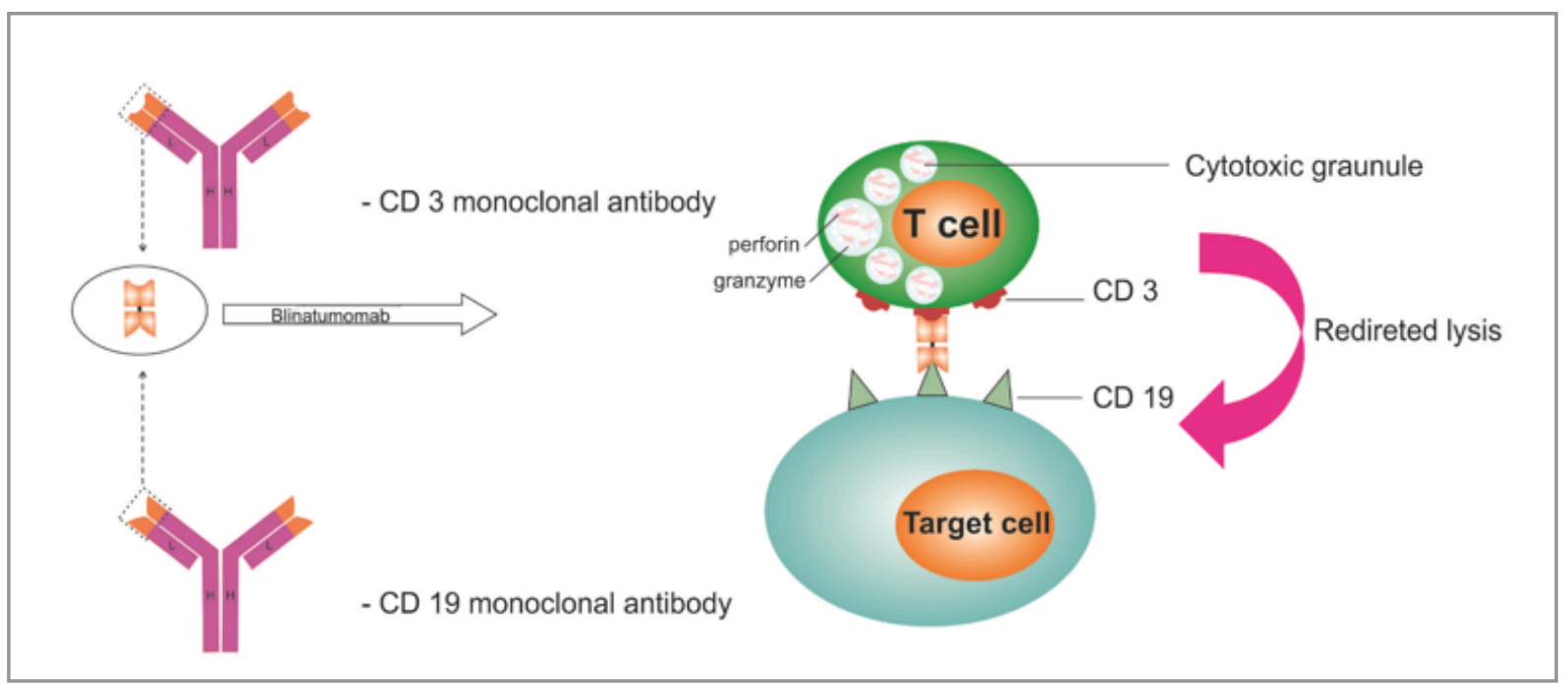

Figure 2. Diagram of the Blinatumomab. The Blinatumomab antibody binds to CD3 on cytotoxic T cells and to CD19 positive leukemia cells. On binding to CD19, cytotoxic perforins and granzymes are released and kill the tumor cell

who achieved MRD negativity. ${ }^{64}$ A phase II trial was also performed to determine clinical activity of blinatumomab in patient with relapsed or refractory BCP-ALL. Overall 36 patients with relapsed or refractory BCP-ALL were treated with blinatumomab in cycles of 4 -week continuous infusion followed by a 2-week treatment-free interval in a single-arm study. Median age of patients was 32 years (range, 18 to 77 years). Twenty-five patients (69\%) achieved a CR or CRh, with $88 \%$ of the responders achieving an MRD response. The estimated median overall survival was 9.8 months, and median Relapse-free survival was 7.6 months. Among the 36 patients treated, the most common AEs, regardless of grade, were pyrexia $(81 \%)$, fatigue $(50 \%)$, headache $(47 \%)$, tremor $(36 \%)$, and leukopenia (19\%). Cytokine release syndrome (CRS) was reported as a clinically important adverse event. ${ }^{65}$ The toxicity and efficacy of blinatumomab was also evaluated in a large confirmatory phase 2 study in 189 patients with relapsed/ refractory disease. Blinatumomab was given by continuous IV infusion (4 weeks on/2 weeks off) for up to 5 cycles. Based on primary analysis $43 \%$ of patients achieved CR/CRh; $80 \%$ of responses occurred within cycle 1 and the overall survival were 6 months, respectively. Regardless of causality, the most common adverse events were pyrexia $(59 \%)$, headache $(35 \%)$ and febrile neutropenia
(29\%). The data support the antileukemia activity of single-agent blinatumomab in patient with $\mathrm{r} / \mathrm{r}$ ALL. ${ }^{66}$ Blinatumomab is currently being evaluated in a phase 3 trial in patients with ALL in first or second relapse and in a phase 2 study in patients with relapsed Philadelphia-positive ALL.

\section{MODERN IMMUNOTHERAPY OF B- CELL MALIGNANCIES INCLUDING ALL WITH CD19-DIRECTED CAR T-CELL}

Chimeric Antigen Receptor T Cell therapy (CAR) is a new strategy for the treatment of relapsed /refractory ALL, which is associated with poor outcome in adults and children. CARs are synthetic, engineered receptors that combine the antigen property of antibodies with the lytic ability and self-renewal of $\mathrm{T}$ cells. ${ }^{67-68}$ CAR-T cells can recognize and kill cancer cells independently of the major histocompatibility complex (MHC). They are composed of ectodomain, a single-chain variable fragment $(\mathrm{scFv})$ derived from monoclonal antibody ${ }^{69}$, transmembrane domain, and an endodomain. CAR specificity is determined by $\mathrm{scFv}$, from the variable portions of both heavy and light chains of a monoclonal antibody, which is linked via a flexible spacer (the hinge region) to the transmembrane domain. The transmembrane domain is located between the hinge and the endodomains 


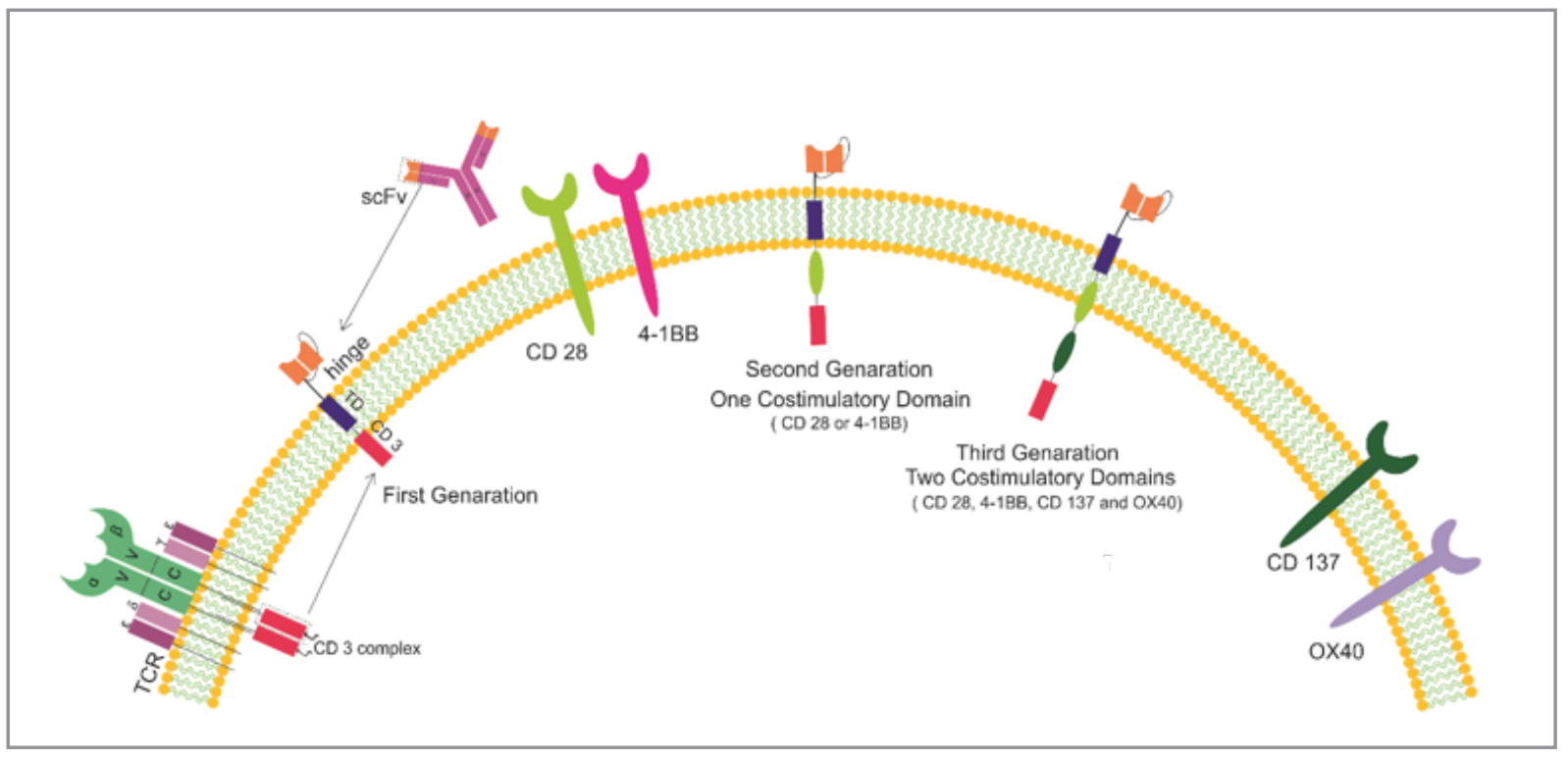

Figure 3. The structure of chimeric antigen receptor. Usually, these receptors comprise a recognition sequence [typically, singlechain variable fragment derived from an antibody (scFv)], a transmembrane domain and an intracellular signaling domain including CD3ל in first generation and other costimulatory domains such as CD28 and tumor necrosis factor receptors such as OX-401 in second and third generation

and usually derived from $\mathrm{CD} 3-\zeta, \mathrm{CD} 4, \mathrm{CD} 8$, or CD28 molecules. The endodomain (intracellular signaling domain) in First-generation CARs derived from $\mathrm{CD} 3-\zeta$. Second-generation CARs comprise a single costimulatory domain derived from CD28 or 4-1BB; and also third-generation CARs comprise two costimulatory domains, a combination of CD28,CD27, 4-1BB, OX40 or ICOS to induce persistence and long-lasting activation of T cells Figure 3. ${ }^{68,70-71}$ To Manufacture CAR T-cell ; allogeneic $\mathrm{T}$ cells are collected from a patient and genetically modified to express a chimeric antigen receptor that will bind to a surface antigen expressed on tumor cells of patient's, following in vitro expansion and propagation, CAR T cells reinfused to the patient. An antigen is expressed on tumor cells, but not on normal cells would be tumor specific and an ideal antigen targeted by CAR-modified T cells. CD19 with nearly universal expression in the majority of B-cell precursor (BCP)-ALLs and B-cell non-Hodgkin lymphomas is an attractive target for CAR-modified T-cell therapy as well as monoclonal antibodies (discussed earlier). ${ }^{46-47,72}$ Thus CD19-targeted CAR T cells are currently being tested in the clinic with very impressive outcomes.

\subsection{CD19-targeted CAR T cells in clinical trials}

CD19-targeted CAR T-cell therapies are the most advanced T-cell therapies which are currently being tested for treatment of B-cell cancers. The clinical evaluation of CAR therapies in ALL have revealed robust activity and remarkable clinical responses. ${ }^{68,73-76}$ In the MSKCC ALL cohort, Davila et al reported $88 \%$ complete response rate in 16 patients with relapsed B-cell ALL. The median age of patients was 50 years and the persistence of 1928z CAR T cells was 1 to 3 month. ${ }^{73}$ A phase 1 dose-escalation trial was also performed by Lee et al to determine clinical activity, maximum tolerated dose, and response rate of CD19-CAR T cells in patients with relapsed or refractory acute lymphoblastic leukemia or non-Hodgkin lymphoma. Overall 21 patients were enrolled and infused with CD19-CAR T cells. The maximum tolerated dose was $1 \times 10^{6} \mathrm{CD} 19-\mathrm{CAR} \mathrm{T}$ cells per $\mathrm{kg}$. All toxicities were reversible, and the complete response rate was $70 \%$ for 20 patients with B-ALL. With a median follow-up of 10 months, overall survival was $51.6 \%{ }^{75}$ In Children's Hospital of Philadelphia (CHOP) and University of Pennsylvania (Penn) phase 1 trials, Mude et al reported 90\% complete response rate in 30 pediatric and adult patients with 
relapsed/refractory ALL. ${ }^{76}$ All the patients had the cytokine-release syndrome which was effectively treated with the anti-interleukin-6 receptor antibody tocilizumab.

\section{CONCLUSIONS}

Developments of therapeutics with monoclonal antibodies in ALL are extremely encouraging. Rituximab has been shown to increase survival of ALL patients in combination with chemotherapy. Inotuzumab and blinatumomab have revealed significant activity even in patients with refractory ALL .The role of monoclonal antibodies and other novel targeted approaches such as engineered T-cell therapies in ALL should be more evaluated. Future studies are needed to evaluate monoclonal antibodies either alone or in combination with other monoclonal antibodies in frontline and salvage therapy for pediatric and adult B-cell ALL. It is hoped that administration of efficient monoclonal antibodies into frontline ALL therapy improve the cure rate and decrease the need for prolonged and intensive chemotherapy schedules. Although CD19- targeted CAR T-cell therapies have been shown marked activity with high response rates in relapsed B-cell ALL, to expand the potential uses of this therapy in future yet new strategies should be evolved to improve the efficacy and toxicity management.

\section{Authors Contribution Role:}

SMM provide the Idea, perform the Search and Write the MS, HNC helped in implementation of the Idea, help in writing and editing MS, Also DMN helped in in writing and editing MS.

\section{REFERENCES}

1. Larson S, Stock W. Progress in the treatment of adults with acute lymphoblastic leukemia. Current Opin Hematol 15: 400-407, 2008.

2. Pui C-H, Mullighan CG, Evans WE, Relling MV. Pediatric acute lymphoblastic leukemia: where are we going and how do we get there? Blood 120: 1165-1174, 2012.

3. O'Leary M, Krailo M, Anderson JR, Reaman GH. Progress in childhood cancer: 50 years of research collaboration, a report from the Children's Oncology Group. Semin Oncol 35: 484-493, 2008.
4. Kantarjian H, Thomas D, Wayne AS, O'Brien S. Monoclonal Antibody-Based Therapies: A New Dawn in the Treatment of Acute Lymphoblastic Leukemia. Journal of Clinical Oncology. 30: 3876-3883, 2012.

5. FitzGerald DJ, Wayne AS, Kreitman RJ, Pastan I. Treatment of hematologic malignancies with immunotoxins and antibody-drug conjugates. Cancer Res 71: 6300-6309, 2011.

6. Thomas DA, O'Brien S, Faderl S, et al. Chemoimmunotherapy With a Modified Hyper-CVADand Rituximab Regimen Improves Outcome in De Novo Philadelphia ChromosomeNegative Precursor B-Lineage Acute Lymphoblastic Leukemia. J Clin Oncol 28: 3880-3889, 2010.

7. Thomas DA, Faderl S, O'Brien S, et al. Chemoimmunotherapy with hyper-CVAD plus rituximab for the treatment of adult Burkitt and Burkitt-type lymphoma or acute lymphoblastic leukemia. Cancer 106: 1569-1580, 2006.

8. Scott SD. Rituximab: a new therapeutic monoclonal antibody for non-Hodgkin's lymphoma. Cancer Pract 6: 195-197, 1988.

9. Maloney DG. Mechanism of action of rituximab. Anticancer Drugs 12 Suppl 2: S1-4, 2001.

10. Piccaluga PP, Arpinati M, Candoni A, et al. Surface antigens analysis reveals significant expression of candidate targets for immunotherapy in adult acute lymphoid leukemia. Leuk Lymphoma 52: 325-327, 2011.

11. Raponi S, De Propris MS, Intoppa S, et al. Flow cytometric study of potential target antigens (CD19, CD20, CD22, CD33) for antibody-based immunotherapy in acute lymphoblastic leukemia: analysis of 552 cases. Leuk Lymphoma 52: 1098-107, 2011.

12. Thomas DA, Faderl S, O'Brien S, et al. Chemoimmunotherapy with hyper-CVAD plus rituximab for the treatment of adult Burkitt and Burkitt-type lymphoma or acute lymphoblastic leukemia. Cancer 106: 1569-1580, 2006.

13. Hainsworth JD. Monoclonal antibody therapy in lymphoid malignancies. Oncologist 5: 376-384, 2000.

14. Weiner GJ, editor Rituximab: mechanism of action. Semin Hematol 47: 115-123, 2010.

15. Thomas DA, O'Brien S, Faderl S, et al. Chemoimmunotherapy with a modified hyper-CVAD and rituximab regimen improves outcome in de novo Philadelphia chromosomenegative precursor B-lineage acute lymphoblastic leukemia. $\mathrm{J}$ Clin Oncol 28: 3880-3889, 2010.

16. Hoelzer D, Huettmann A, Kaul F, et al. Immunochemotherapy with rituximab improves molecular $\mathrm{CR}$ rate and outcome in CD20+ B-lineage standard and high risk patients; results of 263 CD20+ patients studied prospectively in GMALL study 07/2003. Blood 116: 170-170, 2010:

17. Cheson BD. Ofatumumab, a novel anti-CD20 monoclonal antibody for the treatment of B-cell malignancies. J Clin Oncol 28: 3525-3530, 2010. 
18. Teeling JL, Mackus WJ, Wiegman LJ, et al. The biological activity of human CD20 monoclonal antibodies is linked to unique epitopes on CD20. J Immunol 177: 362-371, 2006.

19. Pawluczkowycz AW, Beurskens FJ, Beum PV, et al. Binding of submaximal $\mathrm{C} 1 \mathrm{q}$ promotes complement-dependent cytotoxicity (CDC) of B cells opsonized with anti-CD20 mAbs ofatumumab (OFA) or rituximab (RTX): considerably higher levels of CDC are induced by OFA than by RTX. J Immunol 183: 749-758, 2009.

20. Hagop K, Thomas D, Garcia-Manero G, et al. Phase II study of the hyper-CVAD regimen in combination with ofatumum$\mathrm{ab}$ as frontline therapy for adults with CD-20 positive acute lymphoblastic leukemia (ALL). Blood 122: 2664-2664, 2013.

21. Herter S, Herting F, Mundigl O, et al. Preclinical activity of the type II CD20 antibody GA101 (obinutuzumab) compared with rituximab and ofatumumab in vitro and in xenograft models. Mol Cancer Ther 12: 2031-2042, 2013.

22. Mossner E, Brunker $P$, Moser $S$, et al. Increasing the efficacy of CD2O antibody therapy through the engineering of a new type II anti-CD20 antibody with enhanced direct and immune effector cell-mediated B-cell cytotoxicity. Blood 115: 439343402, 2010.

23. Goede V, Fischer K, Busch R, et al. Obinutuzumab plus chlorambucil in patients with $C L L$ and coexisting conditions. New England Journal of Medicine 370: 1101-1110, 2014.

24. Fischer K, Busch R, Engelke A, et al. Head-to-head comparison of obinutuzumab (GA101) plus chlorambucil (Clb) versus rituximab plus $\mathrm{Clb}$ in patients with chronic lymphocytic leukemia (CLL) and co-existing medical conditions (comorbidities): final stage 2 results of the CLL11 trial. Blood 122: 6-6, 2013.

25. Shah NN, Stevenson MS, Yuan CM, et al. Characterization of CD22 expression in acute lymphoblastic leukemia. Pediatr Blood Cancer 62: 964-969, 2015.

26. Shih LB, Lu HH, Xuan H, Goldenberg DM. Internalization and intracellular processing of an anti-B-cell lymphoma monoclonal antibody, LL2. Int J Cancer 56: 538-545, 1994.

27. Carnahan J, Wang P, Kendall R, et al. Epratuzumab, a humanized monoclonal antibody targeting CD22: characterization of in vitro properties. Clin Cancer Res 9: 3982s-3990s, 2003.

28. Raetz EA, Cairo MS, Borowitz MJ, et al. Chemoimmunotherapy reinduction with epratuzumab in children with acute lymphoblastic leukemia in marrow relapse: a Children's Oncology Group Pilot Study. Journal of Clinical Oncology 26: 3756-3762, 2008.

29. Treumann A, Lifely MR, Schneider P, Ferguson MA. Primary structure of CD52. J Biol Chem 270: 6088-6099, 1995.

30. Hu Y, Turner MJ, Shields J, et al. Investigation of the mechanism of action of alemtuzumab in a human CD52 transgenic mouse model. Immunology 128: 260-270, 2009.
31. Gilleece MH, Dexter TM. Effect of Campath-1H antibody on human hematopoietic progenitors in vitro. Blood 82: 807812, 1993.

32. Keating MJ, Flinn I, Jain V, et al. Therapeutic role of alemtuzumab (Campath-1H) in patients who have failed fludarabine: results of a large international study. Blood 99: 3554-3561, 2002.

33. Hillmen P, Skotnicki AB, Robak T, et al. Alemtuzumab compared with chlorambucil as first-line therapy for chronic lymphocytic leukemia. J Clin Oncol 25: 5616-5623, 2007.

34. Tibes R, Keating MJ, Ferrajoli A, et al. Activity of alemtuzumab in patients with CD52-positive acute leukemia. Cancer 106: 2645-2651, 2006.

35. Angiolillo AL, Yu AL, Reaman G, et al. A phase II study of Campath-1H in children with relapsed or refractory acute lymphoblastic leukemia: a Children's Oncology Group report. Pediatr Blood Cancer 53: 978-983, 2009.

36. Cruz RI, Hernandez-llizaliturri FJ, Olejniczak S, et al. CD52 over-expression affects rituximab-associated complementmediated cytotoxicity but not antibody-dependent cellular cytotoxicity: preclinical evidence that targeting CD52 with alemtuzumab may reverse acquired resistance to rituximab in non-Hodgkin lymphoma. Leuk Lymphoma 48: 2424-2436, 2007.

37. Ricart AD. Antibody-drug conjugates of calicheamicin derivative: gemtuzumab ozogamicin and inotuzumab ozogamicin. Clin Cancer Res 17: 6417-6427, 2011.

38. Thorson JS, Sievers EL, Ahlert J, et al. Understanding and exploiting nature's chemical arsenal: the past, present and future of calicheamicin research. Curr Pharm Des 6: 18411879, 2000.

39. Thomas $X$. Profile of inotuzumab ozogamicin and its potential in the treatment of acute lymphoblastic leukemia. Blood Lymphat Cancer 4: 1-8, 2014.

40. Olejniczak SH, Stewart CC, Donohue K, Czuczman MS. A quantitative exploration of surface antigen expression in common B-cell malignancies using flow cytometry. Immunol Invest 35: 93-114, 2006.

41. Cesano A, Gayko U. CD22 as a target of passive immunotherapy. Semin Oncol 30: 253-257, 2003.

42. Advani A, Coiffier B, Czuczman MS, et al. Safety, pharmacokinetics, and preliminary clinical activity of inotuzumab ozogamicin, a novel immunoconjugate for the treatment of B-cell non-Hodgkin's lymphoma: results of a phase I study. J Clin Oncol 28: 2085-2093, 2010.

43. Kantarjian $\mathrm{H}$, Thomas D, Jorgensen J, et al. Inotuzumab ozogamicin, an anti-CD22-calecheamicin conjugate, for refractory and relapsed acute lymphocytic leukaemia: a phase 2 study. Lancet Oncol 13: 403-411, 2012. 
44. Fayad L, Offner F, Smith MR, et al. Safety and clinical activity of a combination therapy comprising two antibody-based targeting agents for the treatment of non-Hodgkin lymphoma: results of a phase I/II study evaluating the immunoconjugate inotuzumab ozogamicin with rituximab. J Clin Oncol 31: 573-583, 2013.

45. Jabbour E, O'Brien S, Thomas D, Kantarjian H. Inotuzumab ozogamicin in combination with low-intensity chemotherapy (Mini-Hyper-Cvd) as frontline therapy for older patients (>60 years) with acute lymphoblastic leukemia (ALL). Blood 124: 794-794, 2014

46. Aaronson DS, Horvath CM. A road map for those who don't know JAK-STAT. Science 296: 1653-1655, 2002.

47. Del Nagro CJ, Otero DC, Anzelon AN, et al. CD19 function in central and peripheral B-cell development. Immunol Res 31: 119-131, 2005.

48. Blanc V, Bousseau A, Caron A, et al. SAR3419: an antiCD19-Maytansinoid Immunoconjugate for the treatment of B-cell malignancies. Clin Cancer Res 17: 6448-6458, 2011.

49. Oroudjev E, Lopus M, Wilson L, et al. Maytansinoid-antibody conjugates induce mitotic arrest by suppressing microtubule dynamic instability. Mol Cancer Ther 9: 2700-2713, 2010.

50. Lopus M, Oroudjev E, Wilson L, et al. Maytansine and cellular metabolites of antibody-maytansinoid conjugates strongly suppress microtubule dynamics by binding to microtubules. Mol Cancer Ther 9: 2689-2699, 2010.

51. Al-Katib AM, Aboukameel A, Mohammad R, et al. Superior antitumor activity of SAR3419 to rituximab in xenograft models for non-Hodgkin's lymphoma. Clinical cancer research : an official journal of the American Association for Cancer Research 15: 4038-4045, 2009.

52. Carol H, Szymanska B, Evans K, et al. The anti-CD19 antibody-drug conjugate SAR3419 prevents hematolymphoid relapse postinduction therapy in preclinical models of pediatric acute lymphoblastic leukemia. Clinical cancer research : an official journal of the American Association for Cancer Research 19: 1795-1805, 2013.

53. Younes A, Kim S, Romaguera J, et al. Phase I multidose-escalation study of the anti-CD19 maytansinoid immunoconjugate SAR3419 administered by intravenous infusion every 3 weeks to patients with relapsed/refractory B-cell lymphoma. Journal of Clinical Oncology 30: 2776-2782, 2012.

54. Ribrag V, Dupuis J, Tilly $\mathrm{H}$, et al. A dose-escalation study of SAR3419, an anti-CD19 antibody maytansinoid conjugate, administered by intravenous infusion once weekly in patients with relapsed/refractory B-cell non-Hodgkin lymphoma. Clinical Cancer Research 20: 213-220, 2014.

55. Kantarjian HM, Lioure B, Atallah E, et al. A Phase 2 Study of Coltuximab Ravtansine (SAR3419) Monotherapy in Patients with Relapsed or Refractory Acute Lymphoblastic Leukemia (ALL). Clin Lymphoma Myeloma Leuk 16: 139-45, 2016.
56. Fathi $A T$, Shah BD, DeAngelo DJ, et al. A first-in-human phase 1 study of the antibody-drug conjugate SGN-CD19A in relapsed or refractory B-lineage acute leukemia and highly aggressive lymphoma. Blood 122: 1437-1437, 2013.

57. Fathi AT, Borate $U$, DeAngelo DJ, et al. A phase 1 study of denintuzumab mafodotin (SGN-CD19A) in adults with relapsed or refractory B-lineage acute leukemia (B-ALL) and highly aggressive lymphoma. Blood 126:1328-1328, 2015.

58. Moskowitz $\mathrm{CH}$, Fanale MA, Shah $\mathrm{BD}$, et al. A phase 1 study of denintuzumab mafodotin (SGN-CD19A) in Relapsed/Refactory B-lineage non-hodgkin lymphoma. Blood 126:182182, 2015.

59. A phase 2 clinical trial is evaluating $19 \mathrm{~A}$ in combination with chemotherapy for relapsed diffuse large B-cell lymphoma (DLBCL). Available from: http://www.seattlegenetics.com/ sgn-cd19a (access date: 1/6/2016).

60. Topp MS, Kufer P, Gökbuget N, et al. Targeted therapy with the T-cell-engaging antibody blinatumomab of chemotherapy-refractory minimal residual disease in B-lineage acute lymphoblastic leukemia patients results in high response rate and prolonged leukemia-free survival. J Clin Oncol 29: 2493$2498,2011$.

61. Bargou R, Leo E, Zugmaier G, et al. Tumor regression in cancer patients by very low doses of a T cell-engaging antibody. Science 321: 974-977, 2008.

62. Topp MS, Gökbuget N, Zugmaier G, et al. Long-term followup of hematologic relapse-free survival in a phase 2 study of blinatumomab in patients with MRD in B-lineage ALL. Blood 120: 5185-5187, 2012.

63. Handgretinger R, Zugmaier G, Henze G, et al. Complete remission after blinatumomab-induced donor T-cell activation in three pediatric patients with post-transplant relapsed acute lymphoblastic leukemia. Leukemia 25: 181-184, 2011.

64. Topp MS, Goekbuget N, Zugmaier G, et al. Anti-CD19 BiTE blinatumomab induces high complete remission rate and prolongs overall survival in adult patients with relapsed/ refractory B-precursor acute lymphoblastic leukemia (ALL). Blood. 120:670-670, 2012.

65. Topp MS, Gökbuget N, Zugmaier G, et al. Phase II Trial of the Anti-CD19 Bispecific T Cell-Engager Blinatumomab Shows Hematologic and Molecular Remissions in Patients With Relapsed or Refractory B-Precursor Acute Lymphoblastic Leukemia. J Clin Oncol 32: 4134-4140, 2014.

66. Topp M, Goekbuget N, Stein A, et al. Confirmatory openlabel, single-arm, multicenter phase 2 study of the BiTE antibody blinatumomab in patients (pts) with relapsed/refractory B-precursor acute lymphoblastic leukemia ( $r / r$ ALL). J Clin Oncol 32:7005, 2014.

67. Maher J. Immunotherapy of malignant disease using chimeric antigen receptor engrafted T cells. ISRN Oncol 2012:1-23, 2012. 
International Journal of Hematology and Oncology

68. Brentjens RJ, Rivière I, Park JH, et al. Safety and persistence of adoptively transferred autologous CD19-targeted T cells in patients with relapsed or chemotherapy refractory B-cell leukemias. Blood 118: 4817-4828, 2011.

69. Eshhar Z, Waks T, Gross G, Schindler DG. Specific activation and targeting of cytotoxic lymphocytes through chimeric single chains consisting of antibody-binding domains and the gamma or zeta subunits of the immunoglobulin and T-cell receptors. Proceedings of the National Academy of Sciences 90: 720-724, 1993.

70. Barrett DM, Singh N, Liu X, et al. Relation of clinical culture method to T-cell memory status and efficacy in xenograft models of adoptive immunotherapy. Cytotherapy 16: 619630, 2014.

71. Pegram HJ, Park JH, Brentjens RJ. CD28z CARs and armored CARs. The Cancer Journal 20: 127-133, 2014.

72. Scheuermann R, Racila E. CD19 antigen in leukemia and lymphoma diagnosis and immunotherapy. Leukemia \& lymphoma 18: 385-397, 1995.

73. Davila ML, Riviere I, Wang X, et al. Efficacy and toxicity management of 19-28z CAR T cell therapy in B cell acute lymphoblastic leukemia. Sci Transl Med 6: 224ra25-ra25, 2014.

74. Grupp SA, Kalos M, Barrett D, et al. Chimeric antigen receptor-modified T cells for acute lymphoid leukemia. New England Journal of Medicine 368: 1509-1518, 2013.

75. Lee DW, Kochenderfer JN, Stetler-Stevenson M, et al. T cells expressing CD19 chimeric antigen receptors for acute lymphoblastic leukaemia in children and young adults: a phase 1 dose-escalation trial. The Lancet 385: 517-528, 2015.

76. Maude SL, Frey N, Shaw PA, et al. Chimeric antigen receptor $T$ cells for sustained remissions in leukemia. New England Journal of Medicine 371: 1507-1517, 2014.

\section{Correspondence:}

Dr. Hojjatollah Nozad CHAROUDEH

Tabriz University of Medical Sciences

Stem Cell Research Center

Tabriz / IRAN

e-mail: nozadh@tbzmed.ac.ir 